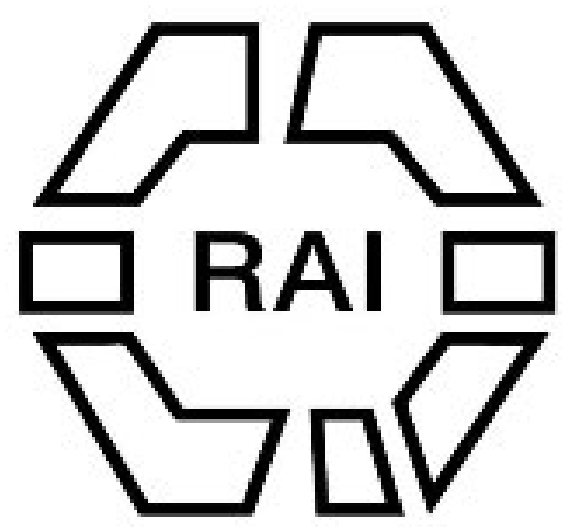

Native Circumcision Lodges in the Zoutpansberg District

Author(s): C. A. Wheelwright

Source: The Journal of the Anthropological Institute of Great Britain and Ireland, Vol. 35

(Jul. - Dec., 1905), pp. 251-255

Published by: Royal Anthropological Institute of Great Britain and Ireland

Stable URL: http://www.jstor.org/stable/2843065

Accessed: 14/06/2014 01:47

Your use of the JSTOR archive indicates your acceptance of the Terms \& Conditions of Use, available at http://www.jstor.org/page/info/about/policies/terms.jsp

JSTOR is a not-for-profit service that helps scholars, researchers, and students discover, use, and build upon a wide range of content in a trusted digital archive. We use information technology and tools to increase productivity and facilitate new forms of scholarship. For more information about JSTOR, please contact support@jstor.org. 


\section{NATIVE CIRCUMCISION LODGES IN THE ZOUTPANSBERG DISTRICT.}

By C. A. Wheelwright, C.M.G.

District Commissioner, Zoutpansberg, Transvaal.

THE following short notes on the above subject are written at the request of Mr. Von Dessauer, the Johannesburg Secretary to the Anthropological Section of the South African Association for the Advancement of Science, and it is hoped that liberal allowances will be made for the numerous shortcomings that must necessarily occur in a subject zealously and secretly guarded by the people indulging in its practices. Had not repeated requests been made for them, the writer would have been somewhat loth to place the notes before the public for some considerable time, or at least until more facts and circumstances had been elicited.

During the year 1904, the native custom of circumcision made itself more pronounced in the Zoutpansberg district than it had done for many years, so much so that anyone dealing with the people and their administration felt bound to collect some notes and data on the subject. The following rough sketch is an attempt to deal with the subject chiefly in relation to its social effects on the native mind.

The custom exists in many parts of South Africa: in the Cape Colony, the Transvaal, Rhodesia, Bechuanaland, etc. It existed at one time amongst the Zulus, but was prohibited by Tshaka at the time he successfully amalgamated the scattered Zulu tribes. It is to this day spoken of as one of Tshaka's master strokes. He issued a proclamation prohibiting the custom, against the advice of those of his councillors, who told him that the people so cherished the custom that he was bound to fail in his attempt to stop it. His order was obeyed, and to this day it is not known amongst the Zulus. The custom of wearing the prepuce cover by the Zulus is traceable to this date and action.

Circumcision is practised throughout the Transvaal, but these remarks are confined to the Zoutpansberg district, where the matter has been under observation. It varies considerably amongst the different people in its methods and practices. A section of the people, known as the Bavenda, would claim probably the most attention, as they have many more customs and manners in relation to the rites than the other people. Those of the Basuto are similar and more uniform, whilst those of the Tshanganas savour of both the Bavenda and Basuto, from whom they have more or less adopted the labit.

Circumcision (Morundo Mgoma of the Sevendit, Lelollo of the Sesutho) in this 
district, seems to have originated with the arrival of a family of people called the Balemba, who seem to have come down with the Bavenda from, as near as can be ascertained, the Congo Valley. It settled itself amongst the Bavenda along and contiguous to the Zoutpansberg, principally in the north and eastern parts. The customs and traditions appertaining to circumcision are kept up principally by these people.

The hereditary circumcision priests are usually members of the Balemba, although in other parts of the district priests from other tribes are not unknown. These people would appear to have come in contact with some Semitic influence. In support of this contention may be mentioned the following observances of the Balemba:-

1. The circumcision.

2. In their own houses they are said not to eat the flesh of animals that have not been killed according to their own customs, principal amongst which is the cutting of the animal's throat by some member of the tribe.

3. They do not eat the blood nor the flesh of pigs.

4. They are supposed not to give their women away in marriage to other tribes, and if they take wives from outside they first have to undergo purifying rites.

Originally the lodges, more commonly called schools, were held at intervals of four or five years. It is essential that there should have been a good harvest, for great quantities of food are required and consumed. The summoning of the lodges was in the hands of the biggest chiefs, such, for instance, in their time, as Modjadjie, Mogato, etc. The occasion of convening a lodge was usually the time when a chief's son was to be circumcised. The remaining members of the tribe attend for the same purpose. Of later years it has become customary for most chiefs and Indunas, or headmen, to hold their own lodges. This is a sign of the declining power of native chiefs. In some cases one or two agree to amalgamate, subject to their social relations with each other, and in others the popularity of the priest attracts individual members.

The time of year selected is usually about April or May, when the harvest is ready. The place selected is some very remote and secluded spot in a river bed, where the cold at night is intense, owing to the time of year, and the situation of the lodge. The cold is calculated, with other hardships, such as whipping and privations, to harden the physique of the young fellows attending, and to make them manly.

The doctor, a priest, i.e., the person who actually performs the operation, is chosen by the chief responsible for the lodge. From that time the appointment becomes hereditary, either through the priest instructing his own son or adopting someone else to teach and instruct in the craft.

The chief convening it gives due notice to the families, who bring their male relations, big and small: the uncircumcised to undergo the operation, and the 
circumcised to perform certain functions allocated to them. The latter all carry long but different wands, signifying their grades in the lodge ; anyone pretending, by means of carrying the emblem, that he has passed initiation, is easily discovered and is severely beaten and roughly handled.

The people sit in a circle, with the uncircumcised candidates in the centre; rising up, they dance round the candidates, who remain on the ground, and proceed to compose songs, which become established and are the only ones permitted in the country during the existence of the lodges.

While the schools last no business is allowed ; work is suspended, disputes, transactions, marriages, etc., do not take place. Intercourse between husband and wife is forbidden. Infringements of regulations are punishable at the discretion of the teachers.

The teachers are said to be of three grades, chosen from previously-circumcised people, are usually young men, and have different functions to carry out. They instruct the newcomers in the laws of the school, punish infringements of the regulations, and dispense the food. The status of each of these is marked by the wand he carries. They are considered as headmen by the gang undergoing circumcision under their tuition, even in matters occurring afterwards. The candidates on entering school usually receive some name, such as Lesiba, Letule etc., which they adopt, much in the same way as the Zulu after enrolment is not infrequently known by the name of his regiment. This name acts as a countersign in time of war and disturbance.

At the actual circumcision, the patient is led into a large assembly of people, and placed sitting on a stone opposite the priest. There may be one or more priests; his or their faces are covered with a veil of skin or other substance. The patient is led by young circumcised men, who promptly seize him, holding his head in such a position that he may not see what is going on. Shouts and screams are raised, and such noise made by the beating of drums, etc., as to completely drown any shrieks, or cries, that the patient may utter, which would be looked upon as cowardly and unmanly. Not infrequently he is in such a frenzied state as to be quite oblivious to what is going on. The prepuce is removed with one stroke of the knife or sharp instrument, and the second skin is more carefully removed. The wound is then wrapped up for four or five days in leaves possessing some curative or healing power. Until the four or five days are over, the patient is not allowed to remove the dressing or to apply any other form of lotion, and is permitted to drink only such water as is given him by the doctors in attendance. When the time is past the patients paint their whole bodies with white clay, which is usually left on, or renewed, until the conclusion of the lodge.

The lodge itself consists of roughly-built barracks, such as natives build in time of war, or for temporary shelters. The arrangements of the huts vary, but the more popular way of building is by joining the huts together in two long rows about 10 feet apart, with doors facing the passage running down the whole length of the construction. Fires are kept up all night along the passage, as also in the 
huts themselves. This is to encourage warmth, no clothing of any description being permitted, except such as the people can plait themselves from grass or palm leaves. These kits are generally made of the same pattern, and are of symmetrical shape, more for appearance than use. The women undergoing initiation have grass ropes twined round them, differing considerably from those worn by the men.

Food is prepared by women either at their own kraals or at some specially appointed place, and is brought once or twice a day and deposited at a fixed spot. At the spot where the food is placed are long laths stuck in the ground, in the form of a barrier, through which no woman dare pass; on to these laths all the grass rings used by the women in balancing the food vessels on their heads are threaded. These laths are supposed to fill up with rings simultaneously with the breaking up of the lodge.

The food is for the general community, and is dispensed by the people responsible for that particular branch. Any that is badly cooked or prepared is rejected and thrown away. The unfortunate person who prepared the rejected food is usually insulted and beaten when she next comes. The women on reaching the appointed place with the food have a formula to go through, by way of announcing their arrival to the teachers. This is made up of obscene epithets, made by the women, and responded to in equally obscene language by the teachers. Having received response to the warning, they place the food on the ground, thread the grass rings, and get away.

The lodges usually last three months, or even longer in some parts. No pupil is under any circumstances supposed to leave the lodge before it is over. During its existence gangs of men are sent round all the villages to incluce by force or persuasion the uncircuincised to attend. If they cinnot be got to attend they are generally persecuted in some way well known to, and effectually carried out by, the community.

Native public opinion drives many to submit to the rites. They are jeered at if they refuse, and are treated to ridicule, such as the following expressions: "You are a woman," "Your eyes are unopened," and perhaps the still greater taunt, "You will not please the women, who prefer circumcised inen"; and it is generally said at the conclusion of the lodges, that the newly circumcised are greatly favoured by the women. During the existence of the school, the occupation of the people is to sing, drill, dance and march about in large bodies, etc. The composition of the songs they are taught is obscene and lewd, bearing entirely on sexual matters. During the period no man attending the lodge is allowed intercourse with his own wife, yet the morals are allowed to become very lax ; prostitution is freely indulged in, and adultery is not viewed with any sense of heinousness on account of the surroundings.

Towards the conclusion of the lodge, the pupils are liable to service, in some shape or form, to their chiefs, rendered principally in wood-cutting, collecting goats, or picking gardens. The school is then concluded, and all huts, utensils, etc., used in connection with it at any time are lestrojed. The pupils wash themselves 
for the first time since entering the lodge, return to ordinary clothing, and proceed in a body to the chief or Induna to pay their fees before being released.

It is said that any deaths occurring amongst inmates during the existence of the school are kept secret and that the bodies are quietly buried in the vicinity without any shape or form of mourning, and the deceased is simply looked upon as having disappeared.

The foregoing remarks are based chiefly on the customs attending the Bavenda, who are more enthusiastic and spend more time at it than any other tribes in the district. The customs of the Basuto tribes (lodges) are much the same, varying, however, in many details. The chief variations, perhaps, are that their schools are made up of three terms, with a vacation of about three years between each. The first term the boys attend as youngsters, they are initiated into the ways of the lodge, and have their faces scarred with sharp instruments. This is very noticeable amongst several of the tribes. At the second term, three years after, the actual circumcision takes place, and at the last term, three years ufter that again, the final initiation is given. Unlike the Bavenda, the Basutos spend as little time as possible in the schools; they have no regular priests or doctors to perform the circumcision, which is done by any volunteer from amongst those present who have been previously initiated and who may be approved. The patient is blindfolded, so that he never gets to know who performed the operation on him.

The influence to attend these lodges is so great that many natives who have become Christians break away from the mission stations and join them. Much immorality occurs in connection with the lodges; debauchery is carried on at which all the candidates and visitors are encouraged to indulge in eating and drinking and licentiousness. That this, and the teaching of doctrines of a debasing nature in respect to sexual relations, etc., go on at the lodges is true, but when one sees the people giving up their whole minds to it, submitting without resistance to the circumcision and putting up with extreme hardships in the way of cold and disease in the lodges, and the entire suspension of their ordinary duties, it makes it difficult to dispel the idea that it is their form of religion or perhaps some cherished national custom handed down to them.

It is most difficult to get any information about the matter. The very greatest secrecy is maintained, and even people who become converts at the mission stations seldon can be got to reveal the facts of what occurs in the lodges. People who have been forcibly taken into the lodges against their wishes and circumcised have, when released by the authorities, refused in many cases to say what occurred to them beyond that they had been circumcised. This has been found from men of 60 or 70 years of age to young boys of 10 or 12 who have been pressed into the lodges. A profound secrecy is maintained by all. At an earlier period in history it is beyond all doubt that any person giving away the oaths they took in the lodges was killed as a punishment. This cannot be done now, but the fact is not hidden that they are impeached in some way which acts as a deterrent, keeping the people to whatever oaths they may have taken. 